\title{
Pengukuran Sentimen Sosial Terhadap Teknologi Kendaraan Listrik: Bukti Empiris di Indonesia
}

\author{
Atha Fitrah Riyadi, Faiz Ramadhani Rahman, M. Aldiansyah Nofa Pratama, M. Khanif Khafidli*, Harry Patria \\ Magister Manajemen Teknologi \\ Institut Teknologi Sepuluh Nopember Kampus ITS Tjokroaminoto \\ Surabaya, INDONESIA \\ riyadhi.atha@gmail.com, faizramadhani09@gmail.com,nofaldiansyah@gmail.com, khanifkhafidli@gmail.com*,harry.patria@sbm-itb.ac.id
}

\begin{abstract}
Currently, climate change due to global warming is a concern for many parties. The greenhouse gas emissions level is increasing day by day. The major contributors to Air pollution are the greenhouse effect. Transportation accounts for about $27 \%$ of air pollution, and governments in various countries use electric vehicles to reduce air pollution. However, the success of using electric vehicles is depending on perception, people's sentiment, and understanding. The main purpose of this research is to find out how public sentiment towards electric vehicles is through tweets and comments on the Twitter social media platform using sentiment analysis. The data obtained are 1084 tweets and comments. The data were classified using the Naïve Bayes method, K-Nearest Neighbor, and Decision Tree. The results showed that the Naïve Bayes Classification Method gave better results than K-Nearest Neighbor, and Decision Tree with an accuracy rate of $94 \%$ positive sentiment by $53 \%$, negative sentiment by $38 \%$, and neutral sentiment by $9 \%$. So, it can be concluded that public sentiment towards electric vehicles is quite good based on conversations on the Twitter social media platform. In addition, the author also visualizes the results of the analysis in the form of graphs and word clouds so that they can help the electric vehicle industry players to understand public sentiment better and more accurately.
\end{abstract}

Keywords: Sentiment Analysis; Electric Vehicles; Climate Change; Social Media.

Abstrak - Saat ini, perubahan iklim akibat pemanasan global menjadi perhatian bagi banyak pihak. Tingkat emisi gas rumah kaca meningkat dari hari ke hari. Polusi udara adalah salah satu kontributor yang berperan signifikan terhadap efek rumah kaca. Transportasi menyumbang sekitar $27 \%$ dari polusi udara, dan pemerintah di berbagai negara mengambil langkah-langkah untuk mengurangi polusi udara dengan mendorong penggunaan kendaraan listrik. Namun keberhasilannya tergantung pada sentimen, persepsi dan pemahaman masyarakat terhadap kendaraan listrik. Tujuan utama penelitian ini adalah untuk mengetahui bagaimana sentimen publik terhadap kendaraan listrik melalui tweets dan komentar di platform sosial media twitter menggunakan analisis sentimen. Data yang diperoleh adalah 1084 tweets dan komentar. Data diklasifikasikan menggunakan metode Nä̈ve Bayes, K-Nearest Neighbor, dan Decision Tree. Hasil penelitian menunjukkan bahwa bahwa Metode Klasifikasi Naïve Bayes memberikan hasil lebih baik dari K-Nearest Neighbor, dan Decision Tree dengan tingkat akurasi 94\% sentimen positif sebesar 53\%, sentimen negatif sebesar 38\% dan sentimen netral sebesar $9 \%$. Sehingga dapat disimpulkan bahwa sentimen masyarakat terhadap kendaraan listrik cukup baik berdasarkan percakapan di platform sosial media twitter. Selain itu, penelitian ini juga memvisualkan hasil analisa dalam bentuk grafik dan word cloud sehingga dapat membantu pelaku industri kendaraan listrik untuk memahami sentimen publik dengan lebih baik dan akurat.

\section{Kata Kunci: Analisis Sentimen; Kendaraan Listrik; Perubahan Iklim; Media Sosial.}

1. Pendahuluan

Perubahan iklim adalah isu yang banyak dibahas oleh berbagai negara secara serius pada masa kini. Kerusakan berbagai ekosistem, perubahan cuaca ekstrem, bencana alam, merupakan akibat terbesar dari perubahan iklim. Salah satu langkah terbaik untuk menekan perubahan iklim adalah dengan mengurangi emisi gas rumah kaca. Jika kenaikan suhu rata-rata di seluruh dunia terus meningkat dan potensi banyak bencana akan terjadi yang menimbulkan kerugian bagi seluruh makhluk hidup maka seluruh pihak dari berbagai negara harus tegas untuk mengambil keputusan untuk mendukung kegiatan yang ramah akan lingkungan.
Tanpa disadari, gas rumah kaca merupakan penyumbang terbesar dalam hal kenaikan suhu rata-rata global akibat kegiatan yang dilakukan manusia. Sebagai contoh penggunaan kendaraan pribadi untuk transportasi sehari-hari masih menggunakan bahan bakar fosil. Bahan bakar fosil merupakan bahan bakar yang turut andil dalam membentuk gas rumah kaca, dari lepasnya karbon monoksida, karbon dioksida hasil pembakaran ke atmosfer tersebut menjadi salah satu penyebab utama terbentuknya gas rumah kaca. Akibatnya lepasnya gas-gas tersebut menjadi penyebab yang kuat terjadinya perubahan iklim dan pemanasan global saat ini.

Dari laporan Climate Transparency Report 2020 [1] dalam upaya mengurangi emisi gas di negara anggota G20 dengan target dari Nationally Determined Contribution 
(NDC), bahwa transportasi adalah penyumbang 27 persen dari polusi udara. Kontributor utama yang signifikan terhadap polusi udara adalah transportasi dengan bahan bakar fosil, dan penggunaan alat berat.

Cara yang dapat diambil untuk mengurangi dan menekan emisi dari gas adalah dengan cara memulai penggunaan kendaraan listrik (electric vehicle) seperti yang dilakukan beberapa negara secara gencar akhir-akhir ini. Contohnya beberapa negara di Eropa perlahan mulai menggunakan kendaraan listrik. Sebuah penelitian di European Environment Agency [2] memperlihatkan kenaikan 3,5 persen penjualan mobil dari tahun sebelumnya merupakan kendaraan listrik dengan rasio 1:9 dari produksi mobil baru tipe hibrida yang rendah emisi dan berpenggerak listrik. Dari kenaikan penjualan tersebut ternyata berkontribusi menurukan emisi CO2 sebesar 12 persen dari tahun sebelumnya berdasarkan jumlah total mobil baru yang terjual, dan menjadi penuruna emisi paling besar sejak tahun 2010 dari mulai penetapan standar produksi mobil di Uni Eropa. 11 persen penjualan mobil baru dari total 11,6 juta yang terdaftar di Uni Eropa, adalah mobil listrik dan hibrida. Peningkatan tren pembelian mobil terus berlanjut meskipun kondisi saat ini masih dalam kondisi pandemi.

Pemerintah Indonesia berkomitmen untuk ikut andil dalam aksi nyata untuk mengurangi emisi dan perubahan iklim dunia. Penggunaan kendaraan listrik atau kendaraan dengan emisi rendah juga diharapkan menjadi tren yang mengikuti tren di Uni Eropa dan secara gencar diaplikasikan di Indonesia. Peraturan Presiden (Perpres) No 55 Tahun 2019 dari Pemerintah Indonesia adalah regulasi pemakaian kendaraan listrik mengenai tranportasi jalan yang menggunakan kendaraan listrik dengan batterai, dan merupakan bukti nyata juga untuk meningkatkan upaya dalam menekan emisi gas dan perubahan iklim. Namun realisasinya, Indonesia masih tertinggal jika dibandingkan dengan Eropa. Dari catatan Gabungan Industri Kendaraan Bermotor Indonesia (Gaikindo) semester I/2020 menunjukkan penjualan kendaraan dengan emisi yang rendah adalah 1.900 unit terdiri dari 1.378 unit kendaraan bybrid, 34 unit kendaraan plug-in bybrid electric vehicle (PHEV) dan 488 unit kendaraan listrik dengan baterai (BEV) [3]. Hal ini juga dikuatkan oleh pernyataan Menteri Perhubungan Indonesia Budi Karya Sumadi bahwa polusi udara terbesar di Indonesia disumbang oleh kendaraan bermotor [4].

Salah satu hal yang berpengaruh terhadap tingkat adopsi kendaraan listrik di suatu negara adalah persepsi masyarakat terhadap kendaraan listrik. Persepsi positif terhadap kendaraan listrik dapat memainkan peran penting untuk mempromosikan kendaraan listrik ini di suatu negara. Tidak hanya terkait permasalahan teknis, namun persepsi sosial juga harus diperhatikan untuk meningkatkan distribusi komersial kendaraan listrik [5]. Sentimen dan perasaan konsumen juga ditemukan mempengaruhi tingkat adopsi kendaraan listrik [6]. Perasaan positif dalam mengendarai kendaraan listrik berkorelasi positif dengan niat konsumen untuk mengadopsi kendaraan listik tersebut. Beberapa konsumen mengungkapkan sentimen mereka seperti "merasa baik" atau "kurang bersalah" setelah mengendarai kendaraan listrik. Di sisi lain, konsumen menyatakan perasaan "malu" setelah mengendarai kendaraan listrik [7]. Temuan dari penelitian lainnya [8] menunjukkan bahwa persepsi positif pada gilirannya akan secara positif pula mempengaruhi niat untuk mengadopsi kendaraan listrik.

Selama beberapa tahun terakhir, terdapat banyak penelitian yang telah menganalisa bagaimana penerimaan pasar terhadap kendaraan hemat energi, banyak peneliti telah mempelajari dan mengidentifikasi faktor-faktor yang mempengaruhi penerimaan dan penolakan pasar terhadap kendaraan listrik. Menurut penelitian [9] disimpulkan bahwa harga, driving range, dan charging rate akan mempengaruhi kepemilikan kendaraan listrik. Sedangkan penelitian di negara tetangga yaitu Singapura mengungkapkan bahwa tingginya biaya Certificate of Entitlement (COE) dan nilai jual kembali menjadi perhatian utama konsumen untuk membeli kendaraan listrik [5]. Faktor penting lainnya untuk adopsi kendaraan listrik adalah kebijakan pemerintah [10]. Kebijakan pemerintah harus dijelaskan dengan baik kepada konsumen, karena jika tidak, kebijakan akan gagal meningkatkan peluang adopsi [11].

Dalam penelitian [12] disimpulkan bahwa jarak jangkauan yang terbatas sejauh 100 mil dianggap cukup untuk memiliki kendaraan listrik sebagai mobil kedua. 34 persen dari peserta penelitian menyatakan bahwa $150 \mathrm{mil}$ akan membuat kendaraan listrik cocok sebagai mobil pertama. Jadi masih menjadi perdebatan bahwa jarak mengemudi kendaraan listrik yang terbatas merupakan penghalang atau tidak terhadap kepemilikan kendaraan listrik. Namun sebuah penelitian lain [13] terhadap 369 pengemudi di Denmark menemukan fakta bahwa jangkauan kendaraan listrik menjadi perhatian nyata karena kurang dari apa yang mereka inginkan dalam kendaraan listrik. Memahami persepsi sosial masyarakat untuk mengetahui hambatan penerimaan kendaraan listrik dapat membantu pelaku industri kendaraan listrik dalam menentukan segmen pasar dan memaksimalkan potensi masa depan kendaraan listrik, terutama di Indonesia.

Saat ini pemanfaatan teknologi informasi berkembang begitu pesatnya. Maka dari itu pemanfaatan teknologi informasi yang tepat dapat dijadikan sebagai salah satu senjata strategic dalam memberikan nilai tambah dalam persaingan bisnis [14], dalam hal ini memanfaatkan teknologi untuk mengetahui bagaimana persepsi sosial masyarakat Indonesia terhadap kendaraan listrik. Teknologi informasi yang dapat digunakan untuk penarikan informasi adalah melalui sosial media. Salah satu platform sosial media yang saat ini diminati oleh masyarakat Indonesia adalah twitter dengan menduduki peringkat ketujuh dari dua belas media sosial yang disediakan yaitu sebesar 27 persen [15]. Tweets maupun komentar publik terkait kendaraan listrik memiliki jumlah yang cukup banyak dengan aliran informasi yang sangat cepat. Salah satu cara untuk menarik kesimpulan terkait bagaimana persepsi masyarakat Indonesia terhadap kendaraan listrik adalah dengan menggunakan analisis sentimen. 
Pada penelitian ini, dilakukan perbandingan metode K-Nearest Neighbor, Naïve Bayes, dan Decision Tree untuk mengetahui sentimen masyarakat Indonesia terhadap kendaraan listrik. Dari penelitian ini diharapkan dapat menjadi bahan rekomendasi kepada pelaku industri kendaraan listrik dan pemerintah Indonesia untuk menentukan kebijakan dan strategi terbaik dalam meningkatkan tingkat adopsi masyarakat Indonesia terhadap kendaraan listrik.

\section{Metodologi}

Data yang digunakan dalam penelitian ini adalah data sekunder yang didapat dengan menggunakan Twitter API (Application Programming Interface) selama 1 Agustus 2021 hingga 30 September 2021. Data tersebut berupa tweets maupun komentar dari pengguna twitter yang mengandung keywords Mobil Listrik, Tesla, Electric Vebicle, Gesits, Mobil SMK, Kendaraan Listrik, dan Motor Listrik.

Dalam penelitian ini menggunakan metode eksperimen. Metode eksperimen adalah metode sistematis yang menghubungkan antara sebab dan akibat. Penelitian ini tergolong penelitian kuantitatif yang memuat kondisi; mengontrol, memanipulasi dan mengamati [16]. Eksperimen dilakukan untuk mendapatkan model terbaik dari beberapa model yang digunakan, diantaranya adalah Nä̈ve Bayes, Decision Tree, dan K-Nearest Neighbor sehingga didapatkan analisa yang akurat terkait sentimen masyarakat Indonesia terhadap kendaraan listrik.

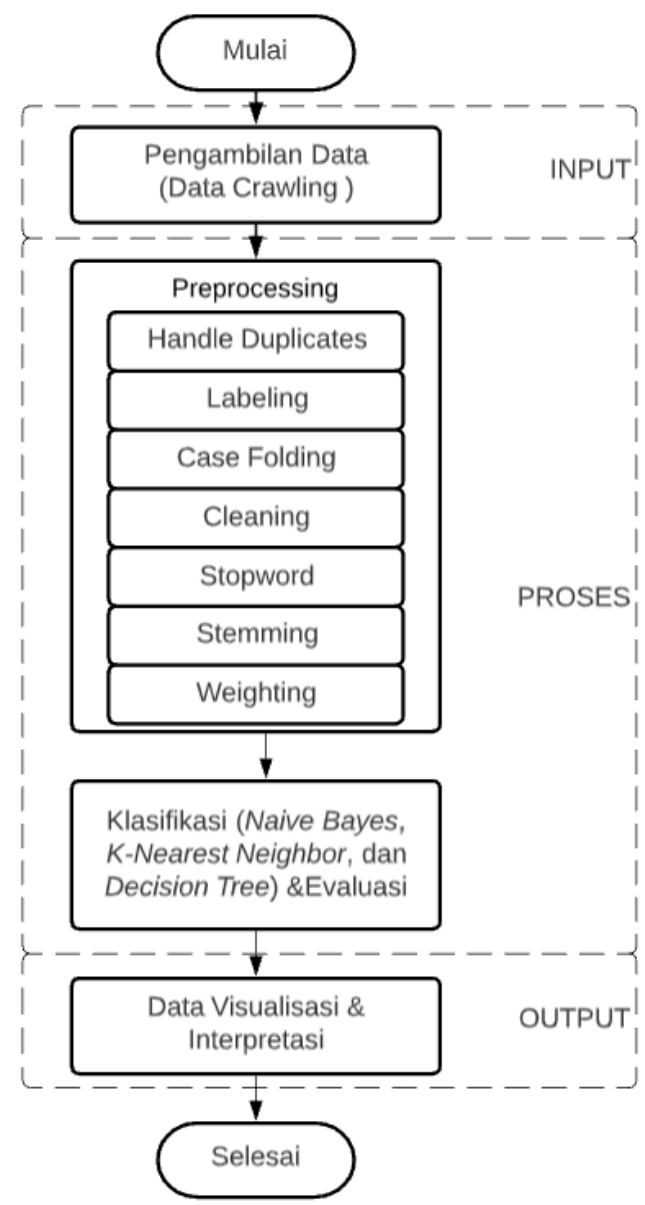

Gambar 1. Metodologi Penenelitian

Kegiatan penelitian ini dibagi menjadi 4 tahap: (1) Data Crawling, (2) Data Preprocessing, (3) Sentiment Analysis dan Evaluation (4) Data Visualization dan Interpretation, seperti pada Gambar 1.

\section{A. Pengambilan Data (Data Crawling)}

Tahap pertama yang dilakukan adalah data crawling yaitu teknik pengumpulan data pada sebuah website dengan menggunakan Uniform Resource Locator (URL). URL ini adalah referensi untuk menemukan semua byperlink di situs website. Kemudian indexing dilakukan untuk menemukan keywords dalam dokumen pada setiap link yang ada. Akses terhadap data tweets di twitter memerlukan hak akses berupa consumer key, consumer secret, access token dan access token secret.

Dimana pada penelitian ini data diambil dari twitter menggunakan Twitter API (Application Programming Interface) dengan keywords Mobil Listrik, Tesla, Electric Vebicle, Gesits, Mobil SMK, Kendaraan Listrik, dan Motor Listrik. 


\section{B. Data Preprocessing}

Tahap kedua adalah data preprocessing. Data yang telah diambil dari twitter dianalisis dan diklasifikasikan. Data preprocessing dilakukan untuk mengolah data mentah menjadi sekumpulan data yang siap digunakan. Secara garis besar, ada dua tujuan data preprocessing yaitu untuk membersihkan data dari data yang jumlahnya ganda dan untuk pemilihan data yang akan diolah dalam dokumen [17].

Berikut data preprocessing yang dilakukan pada penelitian ini: (1) Handle Duplicates: Melakukan filtering terhadap tweets yang memiliki kemungkinan jumlah ganda dalam sekumpulan data yang diperoleh; (2) Labeling: Melakukan proses pelabelan dengan menggunakan dua annotators, output dari annotators pertama akan di cross check oleh annotators kedua; (3) Case Folding: Melakukan pengubahan teks dalam dokumen menjadi bentuk baku yaitu berupa huruf kecil; (4) Cleaning: Menghilangkan komponen tertentu yang terdapat dalam tweets yaitu Uniform Resource Locator (URL), username, RT (Retweet), karakter HTML, dan hashtag; (5) Tokenizing: Melakukan pemecahan teks menjadi kata-kata, dengan metode unigram, bigram, dan trigram; (6) Stopwords Removal: Menghapus kata-kata pada tweets yang terdapat pada daftar stopwords yang telah dibuat; (7) Stemming: Menghilangkan kata imbuhan untuk mendapatkan kata dasar; (8) Weighting: Melakukan proses pembobotan kata dengan TF-IDF.

\section{Sentiment Analysis dan Evaluation}

Tahap ketiga adalah sentiment analysis dan Evaluation dilakukan untuk mengklasifikasikan persepsi sosial masyarakat terhadap kendaraan listrik [5].

Pada eksperiman ini dilakukan beberapa model yang digunakan, diantaranya adalah Nä̈ve Bayes, K-Nearest Neighbor, dan Decision Tree menggunakan aplikasi Rapid Miner sebagai alat analisis. Sebanyak 1084 tweets yang di ambil pada periode bulan 1 Agustus sampai 30 September 2021. Dataset dibagi menjadi $70 \%$ untuk pelatihan dan $30 \%$ untuk pengujian seperti pada Tabel 1 .

Tabel 1. Data Pelatihan dan Pengujian

\begin{tabular}{lc}
\hline Data Pelatihan & 760 \\
Data Pengujian & 325 \\
Total Data & 1084 \\
\hline
\end{tabular}

Hasil dari masing-masing akan dilakukan perbandingan dan dipilih model terbaik dengan melihat tingkat akurasi model berdasarkan Confusion Matrix antara metode Naïve Bayes, K-Nearest Neighbor, dan Decision Tree.

\section{Naïve Bayes}

Nä̈ve Bayes adalah salah satu metode klasifikasi supervised learning yang paling umum digunakan untuk melakukan klasifikasi teks [18]. Untuk melakukan klasifikasi, kita perlu memilih fitur dari data terlebih dahulu. Untuk klasifikasi teks fitur vector juga disebut term vector yang merupakan struktur terpenting selama pelatihan dan proses klasifikasi dimana semua teks tweet akan akan diubah menjadi menjadi term vector untuk diproses oleh klasifikasi. Term vector dihasilkan berdasarkan kosakata unik yang diperoleh dari dataset pelatihan dan tidak ada duplikat dalam kosakata.

Dalam implementasi klasifikasi teks terdapat dua jenis Nä̈ve Bayes yaitu Nä̈ve Bayes Bernoulli dan Nä̈ve Bayes
Multinomial, perbedaan antara keduanya adalah cara dimana fitur diekstraksi dari dokumen. Pada Nä̈ve Bayes Bernoulli, term vector akan diinisialisasi dengan semua elemen menjadi nol, kemudian diperiksa pada setiap kata di kosakata untuk melihat apakah kata tersebut ada di tweet. Jika ada, maka tandai yang sesuai pada elemen dalam istilah vektor ke-1, jika tidak maka tandai yang sesuai pada elemen dalam istilah vektor ke-0, elemen dari term vector tidak hanya mewakili ada atau tidaknya kata namun juga dapat mewakili frekuensi kata.

Misalnya, jika kita memiliki dokumen D, dan kita memiliki kelas C, yang berisi beberapa kelas. Kemudian untuk mendapatkan kelas mana yang dimiliki oleh dokumen $\mathrm{D}$, kita hanya perlu menghitung posterior probability $\mathrm{P}(\mathrm{C} \mid \mathrm{D})$, dan memilih yang terbesar. $\mathrm{P}(\mathrm{C} \mid \mathrm{D})$ bisa dihitung dengan Teorema Bayes (1), di mana prior probability dan likelihood sebelumnya dapat dihitung dari kumpulan data berlabel

$$
\begin{gathered}
\mathrm{P}(\mathrm{C} \mid \mathrm{D})=\frac{\mathrm{P}(\mathrm{D} \mid \mathrm{C}) \mathrm{P}(\mathrm{C})}{\mathrm{P}(\mathrm{D})} \ltimes \mathrm{P}(\mathrm{D} \mid \mathrm{C}) \mathrm{P}(\mathrm{C}) \\
\mathrm{P}\left(S_{i} \mid C_{i}\right) \ltimes \mathrm{P}\left(T_{j} \mid C_{i}\right)=\prod_{j=1}^{|V|}\left[T_{j} P\left(W_{j} \mid C_{i}\right)+\left(1-T_{j}\right)\left(1-P\left(W_{j} \mid C_{i}\right)\right)\right]
\end{gathered}
$$

Berikut adalah cara kerja kedua algoritma ini. Setiap kelas memiliki kemungkinan yang sama, jadi kita bisa dengan mudah mendapatkan prior probability $\mathrm{P}(\mathrm{Ci})$. Biarkan V menjadi kosakata, dan wj adalah kata ke-j di V, jadi dari data pelatihan, kita bisa mendapatkan probabilitas wj milik kelas $\mathrm{Ci}$, yaitu $\mathrm{P}(\mathrm{wj} \mid \mathrm{Ci})$.
Kemudian asumsikan bahwa Si adalah tweet ke-i dalam dataset pengujian, dan $\mathrm{T} j$ adalah term vector untuk tweet ini. Seperti yang telah kita ketahui, Tj berisi 0 dan 1 itu berarti jika sesuai kata dalam kosakata ada di tweet Si. Maka probabilitas tweet $\mathrm{Si}$ milik kelas Ci persamaan (2). 


\section{E. K-Nearest Neighbor}

K-Nearest Neighbor (KNN) adalah salah satu metode machine learning yang masuk dalam kategori supervised learning untuk melakukan klasifikasi teks dan data. Metode K-Nearest Neighbor melakukan klasifikasi terhadap objek berdasarkan data yang jaraknya paling dekat dengan objek tersebut atau biasa dapat disebut neighborhood.
Pada dasarnya tujuan algoritma ini adalah untuk klasifikasi objek dari atribut dan data latih. Jika algoritma tersebut diberikan query maka akan memunculkan data latih yang paling dekat dengan data baru yang dimasukkan dan dengan hasil voting paling banyak akan didapatkan klasifikasi diantara klasifikasi dari k obyek.

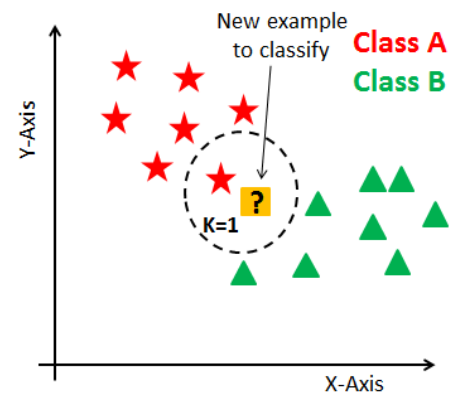

Gambar 2. Model Klasifikasi KNN

Dari data sampel yang digunakan sebagai dimensi dalam penentuan keberadaan data sampel tersebut. Dimensi dibagi menjadi beberapan bagian berdasarkan training sample, dan akan ditandai dengan sebuah titik. Apabila titik tersebut berdekatan dengan $\mathrm{k}$ (Neighbours) maka akan masuk ke dalam kelas tersebut. Euclidean Distance merupakan Metode untuk mencari jarak terdekat.
Berikut persamaan untuk menentukan jarak menggunakan Euclidean Distance [21] (3) yaitu:

$$
\begin{array}{ll}
A i & =k a t a k e-I \text { dokumen Testing atau Uji } \\
B i & =\text { kata ke-I dokumen Training atau Latib } \\
d(A, B) & =J a r a k \text { dokumen A ke dokumen B }
\end{array}
$$

$$
d(A, B)=\sum_{i=1}^{t} \sqrt{\left(A_{1}-B_{1}\right)^{2}+\cdots+\left(A_{i}-B_{i}\right)^{2}}
$$

\section{F. Decision Tree}

Decision Tree adalah flowchart sederhana yang memilih label untuk nilai input. Flowchart ini terdiri dari node keputusan, yang memeriksa nilai fitur, dan leaf node,yang memberikan label. Untuk memilih label nilai input, kita mulai dari flowchart node keputusan awal, yang dikenal sebagai root node. Node ini berisi kondisi yang memeriksa salah satu fitur nilai input, dan memilih cabang berdasarkan nilai fitur tersebut [13].

Mengikuti cabang yang menjelaskan nilai input, kemudian sampai di node keputusan baru dengan kondisi baru pada fitur nilai input. selanjutnya mengikuti cabang dipilih oleh kondisi masing-masing node, sampai di leaf node yang menyediakan label untuk nilai masukan. Untuk klasifikasi teks, node keputusan dapat berupa kata fitur yang telah kita pilih dan leaf node bisa menjadi kategori.

\section{G. Evaluation}

Dalam melakukan evaluasi analisis sentiment terdapat beberapa cara bisa digunakan salah satunya adalah menggunakan acuan confusion matrix atau matrik yang dapat mempresentasikan prediksi dengan kondisi sebenarnya dari data yang dihasilkan oleh algoritma Machine Learning, dengan acuan confusion matrix kita bisa meentukan nilai accuracy, precission, recall dan specifity [19][20]. Accuracy adalah rasio prediksi benar (positif dan negatif) dengan keseluruhan data. Akurasi menjawab pertanyaan "Berapa persen data benar yang relevan dan tidak relevan dari kesuluruhan data uji" seperti pada persamaan (4).

Precission adalah rasio prediksi benar positif dibandingkan dengan keseluruhan hasil yang diprediksi positif, seperti pada persamaan (5).

Recall adalah rasio prediksi benar positif dibandingkan dengan keseluruhan data yang benar positif, seperti pada persamaan (6).

Specifity adalah kebenaran memprediksi negatif dibandingkan dengan keseluruhan data negative, seperti pada persamaan (7) yaitu:

$\begin{array}{ll}\text { False Negative } & =F N \\ \text { False Positive } & =F P \\ \text { True Negative } & =T N \\ \text { True Positive } & =T P\end{array}$

$$
\begin{aligned}
& \text { Accuracy }=\frac{\mathrm{TP}+\mathrm{TN}}{\mathrm{TP}+\mathrm{FP}+\mathrm{FN}+\mathrm{TN}} \times 100 \% \\
& \text { Precision }=\frac{\mathrm{TP}}{\mathrm{TP}+\mathrm{FP}} \times 100 \%
\end{aligned}
$$




$$
\begin{aligned}
& \text { Recall }=\frac{\mathrm{TP}}{\mathrm{TP}+\mathrm{FN}} \times 100 \% \\
& \text { Specifity }=\frac{\mathrm{TN}}{\mathrm{TN}+\mathrm{FP}} \times 100 \%
\end{aligned}
$$

\section{H. Data Visualization dan Interpretation}

Tahap keempat adalah Data Visualization dan Interpretation. Untuk memvisualisasikan hasil analisis pada tahapan sebelumnya, maka dibuatkan data visualization berupa grafik dan word cloud agar hasil analisa dapat lebih mudah dipahami dengan menggunakan berbagai visualisasi yang menarik. Sedangkan interpretation dilakukan untuk mendapatkan kesimpulan dari hasil visualisasi.

\section{Hasil dan Pembahasan}

Penelitian ini telah mengumpulkan semua tweet relevan yang berkaitan dengan Teknologi Kendaraan Listrik. Dibawah ini disajikan hasil untuk klasifikasi sentimen dan memvisualisasikan serta memberikan interpretasi terhadap hasil terkait.

\section{A. Sentiment Analysis}

Eksperimen dilakukan dengan pengklasifikasi sentimen menggunakan algoritma Decision Tree, K-NN, dan Nä̈ve Bayes. Analisis sentimen dari penelitian ini menggunakan software Rapid Miner dengan tambahan text processing extension. Sebelum dilakukan klasifikasi, tweet berbahasa Indonesia diterjemahkan terlebih dahulu ke dalam inggris karena terbatasnya jumlah penelitian klasifikasi teks berbahasa Indonesia.

Gambar 2 menunjukkan kondisi penerimaan masyarakat terhadap Teknologi Kendaraan Listrik di Indonesia pada bulan Agustus hingga September 2021. Dapat terlihat bahwa 53\% masyarakat memberikan sentimen positif, 38\% memberikan sentimen negatif, dan $9 \%$ netral.

Gambar 3 merupakan hasil analisis sentimen menggunakan model dari metode Nä̈ve Bayes. Penelitian ini juga membandingkan metode Nä̈ve Bayes terhadap metode lain untuk mencari metode mana yang terbaik guna mendapatkan model yang yang terbaik. Dilakukan juga analisis sentimen menggunakan metode $K$-Nearest Neighbor dan Decision Tree. Gambar 3 menunjukkan persebaran dan perbedaan yang tidak signifikan antara metode satu dengan yang lainnya

ANALISIS SENTIMEN

TEKNOLOGI KENDARAAN LISTRIK

Netral

$9 \%$

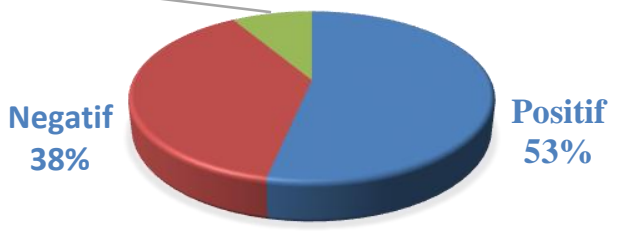

Gambar 2. Hasil Analisis Sentimen

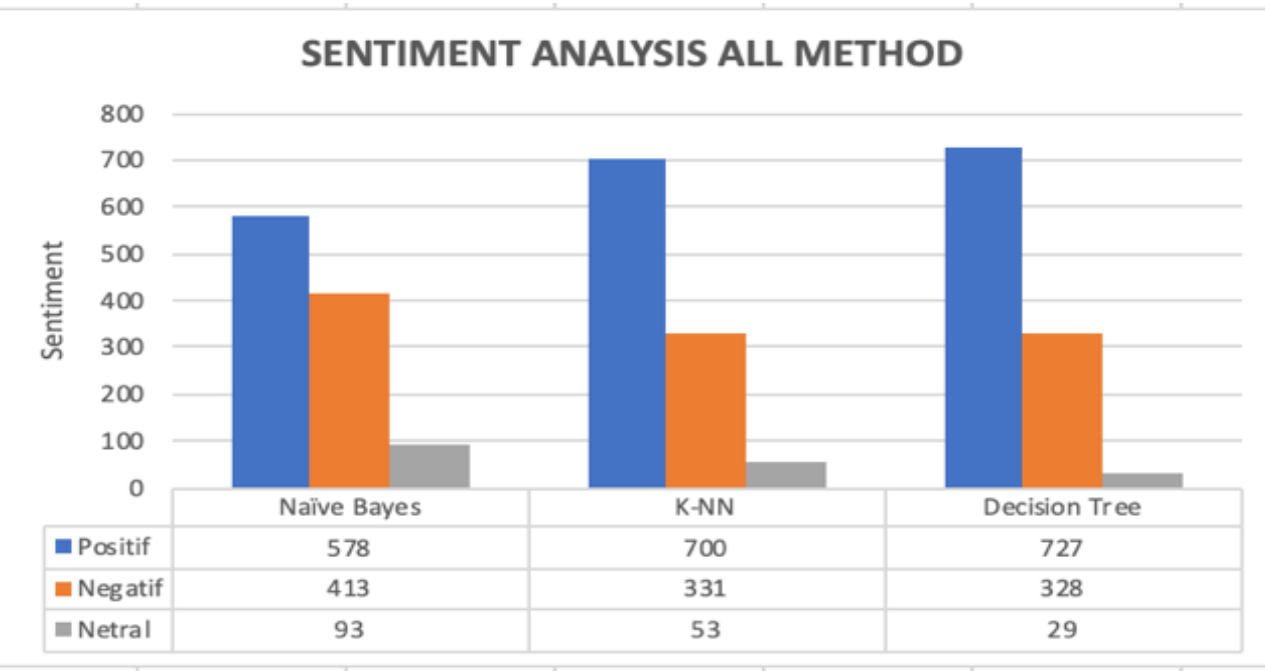

Gambar 3. Perbandingan Hasil Analisis Sentimen Antar Model 


\section{B. Evaluation}

Selanjutnya dari hasil ketiga model yang telah dilakukan. Penelitian ini melakukan evaluasi model untuk membandingkan dan melakukan justifikasi model mana yang terbaik dari ketiga metode yang digunakan guna mencari hasil persebaran sentiment yang paling akurat dari data tweet yang diperoleh.

Gambar 4 menunjukkan bahwa diperoleh hasil akurasi sangat baik yaitu 94\% dari model algoritma Nä̈ve
Bayes dengan perolehan false positif yang relatif lebih besar dibandingkan lain.

Gambar 5 menunjukkan hasil analisa model menggunakan algoritma K-Nearest Neighbor dengan hasil akurasi baik yaitu $92.25 \%$. dengan false negatif dan netral yang relatif lebih besar daripada yang lain.

Gambar 6 menunjukkan hasil analisa model menggunakan algoritma K-Nearest Neighbor dengan hasil akurasi cukup baik yaitu masih di angka $85.61 \%$ dengan false negatif dan netral yang relatif lebih besar dibandingkan yang lain.

\begin{tabular}{|c|c|c|c|c|c|}
\hline pred. Positif & 578 & 0 & 0 & 0 & $100.00 \%$ \\
\hline pred. Negatif & 46 & 367 & 0 & 0 & $88.86 \%$ \\
\hline pred. Netral & 12 & 7 & 74 & 0 & $79.57 \%$ \\
\hline class recall & $90.88 \%$ & $98.13 \%$ & $100.00 \%$ & $0.00 \%$ & \\
\hline
\end{tabular}

Gambar 4. Confusion Matrix Model Nä̈ve Bayes

\begin{tabular}{|c|c|c|c|c|c|}
\hline & true Positif & true Negatif & true Netral & true? & class precision \\
\hline pred. Positif & 634 & 61 & 5 & 0 & $90.57 \%$ \\
\hline pred. Negatif & 2 & 313 & 16 & 0 & $94.56 \%$ \\
\hline pred. Netral & 0 & 0 & 53 & 0 & $100.00 \%$ \\
\hline pred.? & 0 & 0 & 0 & 0 & $0.00 \%$ \\
\hline class recall & $99.69 \%$ & $83.69 \%$ & $71.62 \%$ & $0.00 \%$ & \\
\hline
\end{tabular}

Gambar 5. Confusion Matrix Model K-Nearest Neighbor

accuracy: $85.61 \%$

\begin{tabular}{|c|c|c|c|c|c|}
\hline & true Positif & true Negatif & true Netral & true? & class precision \\
\hline pred. Positif & 610 & 78 & 39 & 0 & $83.91 \%$ \\
\hline pred. Negatif & 25 & 293 & 10 & 0 & $89.33 \%$ \\
\hline pred. Netral & 1 & 3 & 25 & 0 & $86.21 \%$ \\
\hline pred. ? & 0 & 0 & 0 & 0 & $0.00 \%$ \\
\hline class recall & $95.91 \%$ & $78.34 \%$ & $33.78 \%$ & $0.00 \%$ & \\
\hline
\end{tabular}

Gambar 6. Confusion Matrix Model Decision Tree

Tabel 2. Perbandingan Pengukuran Evaluasi Antar Model

\begin{tabular}{lccc}
\hline & Naïve Bayes & $\boldsymbol{K}-\boldsymbol{N N}$ & Decision Tree \\
\cline { 2 - 4 } Accuracy & $94,00 \%$ & $92,25 \%$ & $85,61 \%$ \\
Weighted Mean Recall & $72,25 \%$ & $63,75 \%$ & $52,01 \%$ \\
Weighted Mean Precision & $67,11 \%$ & $71,28 \%$ & $64,86 \%$ \\
\hline
\end{tabular}




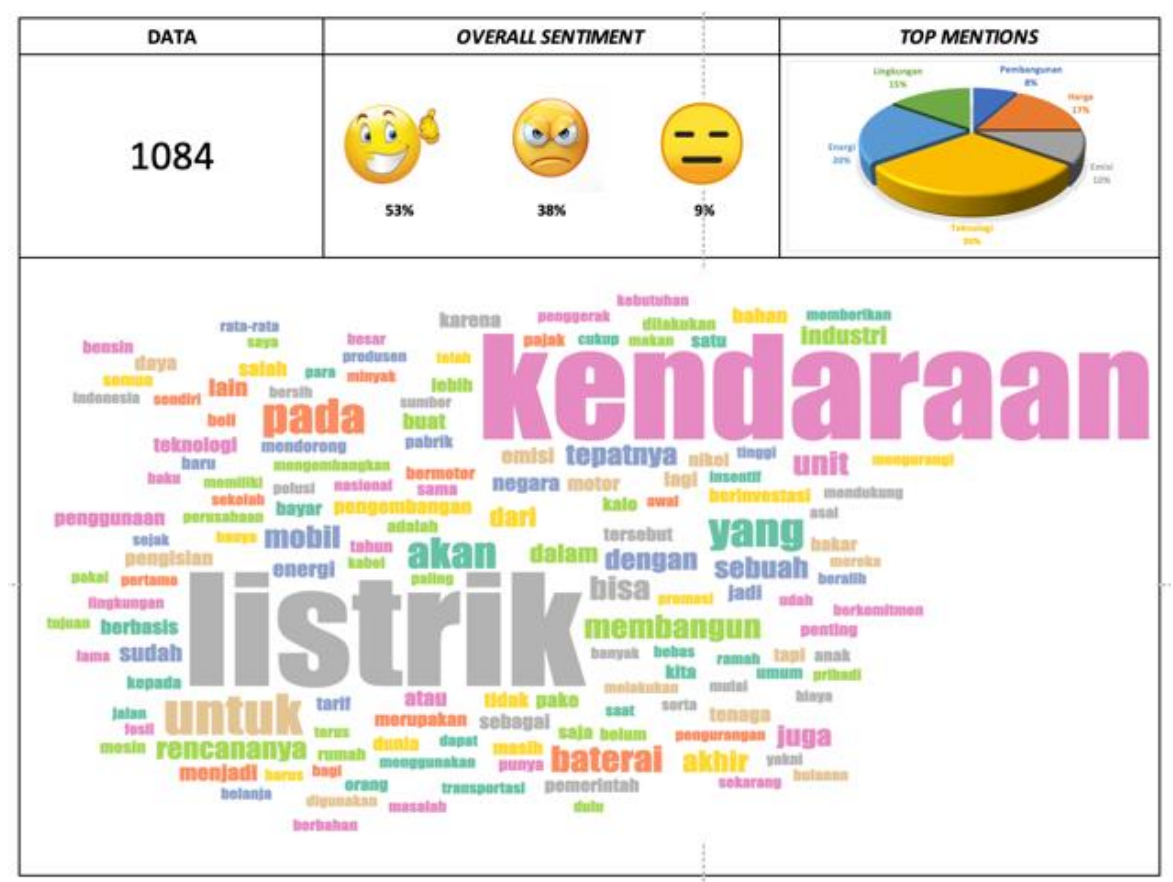

Gambar 7. Visualisasi Data Sentimen

Model evaluasi juga dilakukan dengan melihat weighted mean precision dan recall dari setiap model yang dihasilkan. Tabel 2 memperlihatkan perbedaan hasil evaluasi model dari ketiga metode yang dilakukan.

Hasil evaluasi perbandingan metode dapat dilihat pada Tabel 2 yang menunjukkan bahwa Metode Naïve Bayes merupakan metode yang paling baik dibandingkan dengan Metode K-NN dan Decision Tree untuk mendapatkan model sentiment analisis pada kendaraan listrik diindonesia, hal tersebut dapat dilihat dari hasil evaluasi menggunakan confution matrix nilai Accuracy dan Recall pada metode Naïve Bayes mempunyai nilai paling tinggi dibandingkan dengan metode lain serta nilai Precision lebih rendah sedikit dibandingkan metode $\mathrm{K}$ NN.

\section{Data Visualization dan Interpretation}

Visualisasi data tweet juga dilakukan dengan menggunakan word cloud dan beberapa chart pendukung. Visualisasi ini dapat membantu melihat pembicaraan terbanyak dari masing-masing kata kunci yang terlibat dalam analisa kendaraan listrik ini. Gambar 7 menunjukkan bahwa topik dominan yang terbentuk di kalangan masyarakat pengguna twitter pada bulan Agustus hingga September 2021 terkait topik teknologi kendaraan listrik adalah Lingkungan, Pembangunan, Harga, Energi, Teknologi, dan Emisi.

Interpretasi dari hasil analisis sentimen dan juga visualisasi data terkait penerimaan teknologi kendaraan listrik di Indonesia adalah sudah cukup baik. Ini terlihat dari presentase sentiment positif pada bulan Agustus hingga September 2021 pada media sosial twitter. Hanya saja hal ini dirasa masih kurang optimal dimana masih hampir setengah dari sentimen masyarakat masih merasa teknologi kendaraan listrik ini negatif maupun netizen yang memilih untuk netral dalam mengomentari perkembangan teknologi ini. Perlu adanya optimalisasi terhadap kondisi terkini penerimaan masyarakat dan diharapkan perusahaan teknologi kendaraan listrik dan pemerintah selaku pemangku kebijakan dapat saling mendukung dalam upaya meminimalisi penggunaan emisi karbon di Indonesia yang akan berdampak positif terhadap lingkungan.

\section{Kesimpulan}

Analisis pengukuran sentimen masyarakat dan visualisasi ini dimaksudkan untuk membantu para pelaku industri kendaraan listrik dalam memahami kondisi penerimaan masyarakat terhadap teknologi kendaraan listrik di Indonesia. Penelitian ini menggunakan data media sosial twitter sebagai sumber untuk melihat peta sentimen terhadap industri kendaraan listrik. Berdasarkan hasil perbandingan metode Naïve Bayes, K-NN dan Decision Tree yang telah dilakukan untuk mendapatkan model sentiment analisis pada kendaraan listrik diindonesia diperoleh bahwa metode klasifikasi yang terbaik adalah menggunakan Metode Naïve Bayes dengan tingkat accuracy 94\% Recall 72,25\% dan Precision $67,11 \%$ serta hasil analisis sentimen didapatkan sebesar $53 \%$ memberikan sentimen positif, 38\% memberikan sentimen negatif dan $9 \%$ netral terhadap teknologi kendaraan listrik

Pengukuran sentimen analisis terhadap penerimaan masyarakat di Indonesia menggunakan Metode Naïve Bayes, K-NN dan Decision Tree semuanya memberikan hasil respon sentiment positif dominan atau lebih dari $50 \%$ pada masing-masing metode, ini memberikan gambaran bahwa penerimaan masyarakat di Indonesia masih bisa untuk dioptimalkan kedepannya. Dibutuhkan peran bersama oleh perusahaan teknologi kendaraan 
listrik maupun pemerintah sebagai pemangku kebijakan untuk lebih intense dalam memberikan informasi yang menarik ke seluruh omnichannel media di tanah air terkait seberapa bermanfaatnya teknologi ini. Promosi dan sosialisasi diikuti dengan perubahan kebijakan yang tepat guna akan dapat membantu menyusul ketertinggalan terhadap negara-negara Eropa dalam upaya meminimalisir jumlah emisi gas rumah kaca di Indonesia.

Penelitian ini memberikan rekomendasi untuk pengembangan penelitian di masa depan. Penerapan analisis sentimen dalam time frame yang lebih besar dan dengan jumlah tweet yang lebih besar menjadi tantangan tersendiri untuk penelitian kedepannya termasuk penggunaan metode lexixon sentiment analysis untuk membantu mesin dalam melakukan klasifikasi daripada membiarkan mesin belajar sendiri. Pengembangan penelitian juga dapat dilakukan dengan mengekstraksi data dari platform media sosial lainnya seperti Facebook, Instagram, Youtube dan media-media online.

\section{Daftar Pustaka}

[1] Climate Transparency, "The Climate Transparency Report," Annual G20 Report, 2020.

[2] European Environment Agency, "Electric Vehicle in Europe," EEA Report., no. 20/2016, 2016.

[3] Gaikindo "Harga dan Infrastruktur Jadi Tantangan Mobil Listrik Indonesia," 2021.

[4] Tempo, "Menhub: Polusi Udara Disumbang Penggunaan Motor dan Mobil,” Bisnis Tempo, 2020.

[5] Min, X., Qiang, M., \& Yisi, L., "Public's perception of adopting electric vehicles: A case study of Singapore," Journal of the Eastern Asia Society for Transportation Studies, 12, 2017.

[6] Christidis, P., \& Focas, C., "Factors affecting the uptake of hybrid and electric ve- hicles in the European Union," Energies, 12(18), 3414, 2019.

[7] Graham-Rowe, E., Gardner, B., Abraham, C., Skippon, S., Dittmar, H., Hutchins, R., \& Stannard, J., "Mainstream consumers driving plug-in battery-electric and plug-in hybrid electric cars: A qualitative analysis of responses and evaluations,". Transportation Research Part A, 46, 140-153, 2012.

[8] Schuitema, G., Anable, J., Skippon, S., \& Kinnear, N., "The role of instrumental, hedonic and symbolic attributes in the intention to adopt electric vehicles," Transportation Research Part A: Policy and Practice, 48, 39-49, 2013.
[9] Yang, S., Deng, C., Tang, T., \& Qian, Y., "Electrical vehicle's energy consumption of carfollowing models," Nonlinear Dynamics, 71, 323 $329,2013$.

[10] Sun, X., \& Xu, S., “'The impact of government subsidies on consumer preferences for alternative fuel vehicles," J. Dallan Univ., Technol., (Soc. Sci), 3, 8-16, 2018.

[11] Lane, B., \& Poter, S., "The adoption of cleaner vehicles in the UK: Exploring the consumer attitude-action gap," Journal of Cleaner Production, 15, 1085-1092, 2007.

[12] Skippon, S., \& Garwood, M., "Responses to battery electric vehicles: UK consumer attitudes and attributions of symbolic meaning following direct experience to reduce psychological distance," Transportation Research Part D, 16, 525-531, 2011.

[13] Jensen, A. F., Cherchi, E., \& Mabit, S. L., “On the stability of preferences and attitudes before and after experiencing an electric vehicle," Transportation Research Part D. Transport and Environment, 25, 24-32, 2013.

[14] Wijaya, A., \& Sensuse, D. I., "Perencanaan Strategis Sistem Informasi dan Teknologi Informasi Pada Perusahaan Otomotif dengan Menggunakan Metodologi Tozer," Seminar Nasional Aplikasi Teknologi Informasi, 2011.

[15] Databooks, "Data Publish," Online, KataData, 2018.

[16] Nazir, M., "Metode Penelitian,” Bogor: Ghalia Indonesia, 2017.

[17] Mujilahwati, S., "Pre-processing Text Mining Pada Data Twitter," Sentika. pp.49-56, 2016.

[18] Witten. H.I and Frank.E, "Data mining Practical Machine Learning Tools and Techniques Second Edition," Elsavier, SanFransisco, 2005.

[19] Yousef, Ahmed Hassan, Walaa Medhat, and Hoda Korashy Mohamed. "Sentiment Analysis Algorithms and Applications: A Survey." (2014).

[20] Muhazir, Nurul Huzna., Omar, Faizal Mohd,. Nawi, Mohd Nasrun Mohd. "Sentiment Analysis Visualization System for The Property Industry." (2018).

[21] Alrajak, M.Suyudi., Ernawatu, Iin,. Nurlaili, Ika. "Analisis Sentimen terhadap Pelayanan PT PLN di Jakarta pada Twitter dengan Algoritma $K$ Nearest Neighbor (K-NN)." (2020). 